\begin{tabular}{ccc}
\hline & $\begin{array}{c}\text { International Journal of Health Services } \\
\text { Research and Policy } \\
\text { www.dergipark.org.tr/ijhsrp }\end{array}$ \\
$\begin{array}{c}\text { INTERNATIONAL } \\
\text { ENGINEERING } \\
\text { SCIENCE AND } \\
\text { EDUCATION GROUP }\end{array}$ & e-ISSN: $2602-3482$ & IJHSRP \\
\hline
\end{tabular}

Research Article

\title{
DOES PROFESSIONAL VITALITY OF HEALTH CARE WORKERS CHANGE THEIR LEARNED HELPLESSNESS?
}

\section{Hilal KUŞCU KARATEPE ${ }^{* 1}$ (]) Fatma Nuray KUŞCU ${ }^{2}$ (]) Ebru GÖZÜYEŞILL ${ }^{3}$ (])}

${ }^{1}$ Osmaniye Korkut Ata University, Faculty of Health Sciences, Nursing Department, Osmaniye, Turkey hkuscukaratepe@osmaniye.edu.tr

${ }^{2}$ Hatay Mustafa Kemal University, Vocational School of Health Services, Medical Services and Technical Department, Hatay, Turkey fatmanuraykuscu@mku.edu.tr

${ }^{3}$ Cukurova University, Faculty of Health Sciences, Department of Midwifery, Adana, Turkey egozuyesil@cu.edu.tr

*Corresponding author; hkuscukaratepe@osmaniye.edu.tr

\begin{abstract}
This study was conducted to determine the effects of professional vitality levels on the learned helplessness of healthcare workers during the Covid-19 pandemic process. This descriptive and cross-sectional study was carried out with 200 healthcare workers using the Personal Information Form, Professional Vitality Scale, and Learned Helplessness Scale. SPSS 21 and AMOS 22 programs were used in the analysis of the data. In the evaluation of the data; percentage, average, Pearson correlation analysis, simple and multiple regression analysis methods were preferred. The significance level of the data was considered to be significant at the level of $p<0.05$. It was determined that the professional vitality levels of healthcare workers were at a high level (3.82 \pm 0.48$)$ and that

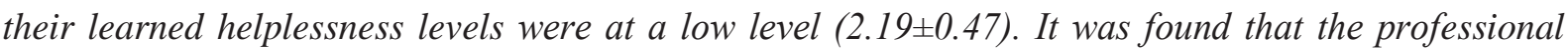
vitality levels of healthcare workers have a significant and negative effect on learned helplessness. Among the sub-dimensions of the Professional Vitality Scale, mastery and job satisfaction subdimensions affect learned helplessness significantly and negatively; passion and vigor subscales were found to have no significant effect on learned helplessness. In the process of the Covid-19 pandemic, professional vitality levels of healthcare workers have an impact on learned helplessness.
\end{abstract}

Keywords: Covid-19, Healthcare Workers, Professional Vitality, Learned Helplessness.

Received: July 9, 2020

Accepted: December 31, 2020

\section{Introduction}

Coronavirus (Covid-19) has caused an outbreak of acute and infectious pneumonia all over the world $[1,2]$ becoming a major worldwide public health concern [3]. In public health events, many causes like sudden developments, uncertainty, and damages caused by insecurity, emotional pressure, deterioration of the balance of life [4] have caused that the important life routines and life perspectives 
of people changed, and everybody experienced intense stress. Healthcare workers are the professional group that was affected at the highest level by this process. Just like it is the case in all healthcare practices, healthcare workers have been at the forefront during this epidemic and faced intense obligations.

Healthcare workers experience physical and psychosocial problems specific to this field, different from public life during the Covid-19 pandemia process. Increasing workload [3], long working hours [5, 6, 7], uncertainties [4], inadequate resources [8], fear of infection, physical burnout, being infected and infecting others $[9,10]$, use of protective equipment that makes it difficult to meet event compulsory needs [11,3], insomnia [12], rapidly changing recommendations and information [13], not being familiar with specific work environments and procedures, facing the pain and death of patients, long-term separation from family members [14], intense work stress [11], psychological helplessness, lack of knowledge [15], fear, anxiety [16], depression [17, 18, 19, 3, 16, 20], and unmet physical and emotional needs [12] are the main problems in this process. These problems are expected to have effects on the professional vitality of healthcare workers, and prepare the ground for learned helplessness in the long run.

Providing and maintaining the professional vitality of healthcare workers who play important roles in a pandemia is important in many respects. Professional vitality is an effective and pioneer variable of positive organizational output in works [21, 22]. The reason why professional vitality is one of the important study fields for researchers is that it is the energy source improving the performance in work, enabling employees to perform their tasks successfully [23]. The employee's success in their work depends on the sense of learning and vitality [24]. It is also a source for employee's practical self-demonstration, dealing with their roles, and direct their energy to physical, cognitive, and emotional efforts related to their work [25]. Employees who feel high vitality levels tend to see things positively and expect positive events to be repeated [23]. For this reason, it is associated with higher job performance [26], better mental health [27], and better stress coping [28]. It may be speculated that professional vitality is a very important element in organizational success outcomes like organizational commitment, performance, job satisfaction, burnout, security, vigor, and strength [23].

During the pandemia process, healthcare workers have experienced learned helplessness from time to time. The factors that affect this include the ever-changing and deepening knowledge burden or the uncertainty regarding the process, the rapidly increasing number of cases [3], workload, physical and mental burnout, fatigue, pessimism, fear of death and infection, concern for patients and family members [16]. Negative mental health outcomes like post-traumatic stress disorder, isolation, depression, anxiety, and loneliness [29] can also cause learned helplessness in healthcare workers infected with Covid-19 and quarantined. These long-term and intense difficulties can turn into learned helplessness, which is another organizational variable.

Learned helplessness is mental learned helplessness caused by repeated (and failed) attempts to escape from this damaging situation in the Covid-19 process [30]. In the literature, learned helplessness was first revealed by Seligman et al. as a result of animal experiments in the late 1960s. By the 1970s, experiments were done on humans. When creatures realized that their behaviors had no impact on an event and condition, they showed the learned helplessness reaction [31]. It is possible to argue that learned helplessness has negative consequences both in individual and organizational terms. It highly avoids organizational learning and changes in employees. In organizations where 
organizational learning is at low levels, change, adaptation to the environment, innovation, productivity, and achieving missions become also difficult $[32,33]$, which causes depression and negative consequences in the work-life of the individual. This can lead to a decrease in the productivity of the institution and the employee, increase corporate expenses, and cause unnecessary reductions in domestic energy.

In this context, it is an already known fact that healthcare workers perform very important roles under very difficult working conditions in this pandemia process affecting the whole world. The present study is projected to shed light on the plans made to determine the level at which health workers can sustain their vitality during this critical period, to reveal their helplessness feelings, and to strengthen in this fight.

The hypotheses developed in line with the purpose of the study and the examinations performed are given below (Table 1).

Table 1. The hypotheses developed in the scope of the study

\begin{tabular}{ll}
\hline $\mathrm{H}_{1}$ & Professional vitality affects learned helplessness in a significant and negative way. \\
$\mathrm{H}_{1 \mathrm{a}}$ & Professional vitality passion sub-dimension affects learned helplessness in a significant and negative way. \\
$\mathrm{H}_{1 \mathrm{~b}}$ & Professional vitality vigor sub-dimension affects learned helplessness in a significant and negative way. \\
$\mathrm{H}_{1 \mathrm{c}}$ & Professional vitality mastery sub-dimension affects learned helplessness in a significant and negative way. \\
$\mathrm{H}_{1 \mathrm{~d}}$ & Professional vitality job satisfaction sub-dimension affects learned helplessness in a significant and negative way. \\
\hline
\end{tabular}

\section{Method}

\subsection{Purpose and Design of the Study}

The purpose of the present study was to determine the changes in professional vitality levels of healthcare workers on learned helplessness. The study had a descriptive and sectional design.

\subsection{The Place and Time of the Study}

The study was conducted with two public and state health workers in Turkey between 01.04.2020 and 30.04.2020.

\subsection{Universe and Sampling of the Study}

The universe of the study was all the healthcare workers working in two public and state hospitals in Turkey, and the sampling consisted of 200 healthcare workers who agreed to participate in the study on the study date and were selected with the random sampling method.

\subsection{Data Collection Tools}

Personal Information Form. A Personal Information Form consisting of 8 questions to determine the socio-demographic characteristics of healthcare workers. It included statements regarding the gender, marital status, age, educational level, total professional year in the healthcare sector, total working year in the current institution, recommending their profession, choosing the profession, and determining the weekly working time.

Professional Vitality Scale. It was developed by Harvey [34]. The validity and reliability study of the scale was conducted by Uzunbacak and Akçakanat [35]. Cronbach Alpha was 0. 89. The scale consists of 18 items and 4 sub-dimensions. The dimensions that make up the scale are passion, vigor, 
mastery, and job satisfaction subcomponents. Among these, passion and vigor dimensions have 4 items each, and mastery and job satisfaction have 5 items each. The scoring of the scale is rated in 5Point Likert style (1= I Absolutely Disagree, 5= I Absolutely Agree). High scores received from the scale shows that professional vitality levels are increasing in terms of each dimension.

The 4-factor structure of the scale was tested with the Explanatory and Confirmatory Factor Analysis in the study. The "Kaiser-Meyer-Olkin Measure of Sampling Adequacy" was 0.82, and the "Bartlett's Test of Sphericity Sig." value was statistically significant. The explained variance was 67.29\%. As a result of the Varimax Rotation Method used for the 4-factor structure of the scale, it was seen that the scale was collected in the 4-factor structure again. Items 4, 10. and 15 were eliminated from the scale because factor loads were below 0.40. It was determined in the new structure of the scale that the passion dimension consisted of 3 items, and the vigor, mastery, and job satisfaction subdimensions consisted of 4 items each. The structural validity of the scale was tested with the Confirmatory Factor Analysis. As a result of the CFA analysis, the goodness of fit index values of the scale was adequate (Table 2).

Learned Helplessness Scale This scale was developed by Quđnless and Nelson, and its validity and reliability study was conducted by Boysan [36, 37]. However, another validity and reliability study was conducted by Yavaş later[38]. Cronbach Alpha was respectively $0.63,0.80$. In this study, the Learned Helplessness Scale that consisted of 15 items and 2 subdimensions and whose reliability and validity study was conducted again were used [38]. It is in the form of 5-Point Likert. Scale items were scored as "Always $=5$, Mostly $=4$, Sometimes $=3$, Very Rarely $=2$, and Never $=1 "$ ". Items 2, 3, $5,7,9,11,13$, and 14 were reverse items. As the total score received from the scale increases, the level of learned helplessness also increases.

The Explanatory and Confirmatory Factor Analyses were made to test the new structure of the scale with 2 factors. The "Kaiser-Meyer-Olkin Measure of Sampling Adequacy" was 0.82, and the "Bartlett's Test of Sphericity Sig." value was statistically significant. The explained variance rate was $60.04 \%$. As a result of the Varimax Rotation Method for the 2-factor structure of the scale, it was found that the scale items were collected under one factor. A total of 9 items were removed from the analyses because their factor loads were below 0.40 . The structural validity of the single-factor scale was tested with Confirmatory Factor Analysis. The goodness of fit index values was found to be adequate (Table 2).

Table 2. Results of professional vitality and learned helplessness DFA analysis goodness of fit index values

\begin{tabular}{ccccc}
\hline $\begin{array}{c}\text { The goodness of Fit } \\
\text { Indices }\end{array}$ & Good Fit & Acceptable Fit & $\begin{array}{c}\text { Professional Vitality Learned Helplessness } \\
\text { Scale }\end{array}$ \\
\hline$\chi^{2} / \mathrm{df}$ & $0 \leq \chi^{2} / \mathrm{df} \leq 2$ & $2<\chi^{2} / \mathrm{df} \leq 5$ & 2.42 & 2.30 \\
RMSEA & $0 \leq \mathrm{RMSEA} \leq .05$ & $.05<\mathrm{RMSEA} \leq .08$ & 0.08 & 0.08 \\
RMR & $0 \leq \mathrm{RMR} \leq .05$ & $.05<\mathrm{RMR} \leq .08$ & 0.06 & 0.04 \\
IFI & $0.95 \leq \mathrm{IFI}<1.00$ & $0.90 \leq \mathrm{IFI}<0.95$ & 0.92 & 0.94 \\
CFI & $0.95 \leq \mathrm{CFI}<1.00$ & $0.90 \leq \mathrm{CFI}<0.95$ & 0.90 & 0.94 \\
GFI & $0.95 \leq \mathrm{GFI}<1.00$ & $0.80 \leq \mathrm{GFI}<0.95$ & 0.94 & 0.97 \\
AGFI & $0.95 \leq \mathrm{GFI}<1.00$ & $0.80 \leq \mathrm{GFI}<0.95$ & 0.90 & 0.91 \\
NFI & $0.95 \leq \mathrm{GFI}<1.00$ & $0.90 \leq \mathrm{GFI}<0.95$ & 0.90 & 0.91 \\
\hline
\end{tabular}




\subsection{Data Collection}

The data were collected with the own budget of the researchers. The survey forms were delivered face-to-face and with WhatsApp to the healthcare workers who volunteered to participate in the study. The surveys were described in the Google Drive online survey system.

\subsection{The Analysis of the Data}

The SPSS 21 and AMOS 22 Package Programs were used in analyzing the data. Normal distribution analysis of the data was made firstly in determining the analysis methods to be used (Table 3). Skewness and Kurtosis values of the data were examined. The normal distribution assumption was met as a result of the Skewness and Kurtosis values of the data were between -1 and +1 [39]. The Cronbach Alpha values of the scales showed that the scale variables were highly reliable. Percentages, mean values, Pearson Correlation Analysis, simple and multi-regression analysis methods were preferred in the evaluation of the data. The values were considered significant at $\mathrm{p}<0.05$ level.

Table 3. Normal distribution and Cronbach Alpha values of the scales used in the study

\begin{tabular}{lccc}
\hline & Skewness & Kurtosis & Cronbach Alpha \\
\hline Passion & -.453 & .516 & 0.78 \\
Vigor & -.083 & -.269 & 0.72 \\
Mastery & -.032 & -.085 & 0.75 \\
Job satisfaction & .077 & -.877 & 0.84 \\
Professional Vitality & .254 & -.557 & 0.87 \\
Learned helplessness & .429 & .127 & 0.79 \\
\hline
\end{tabular}

Ethical Permission: Before the commencement of the study, the ethical board permission was obtained from the Scientific Research and Publishing Ethics Board of Osmaniye Korkut Ata University (dated 19.03.2020. and with the registry number E.1896). The participants took part in the study on a voluntary basis. Institutions were informed.

The Limitations of the Study: The study was limited to the healthcare workers, who were accessible and accepted voluntarily to participate to the study, and who were working at the hospital on the specified dates. The obstacles that emerged with pandemia were the most important limitations of the study. The small number of active workers limited the sampling. Also, the delivery of surveys to participants under prevention measures, the increased workload, and stress due to pandemia made it difficult for workers to fill out the surveys. The assumption that participants answered the surveys honestly and sincerely was another limitation of the study.

\section{Findings}

The socio-demographic characteristics of the healthcare workers are shown in Table 4. A total of $83 \%$ of the healthcare workers were female, and $17 \%$ were male. In terms of marital status, $49 \%$ were married, and $51 \%$ were single. In terms of educational status, $11 \%$ said that they were highschool graduates, $9.5 \%$ had an associate degree, $55.5 \%$ had an undergraduate degree, and $24 \%$ had post-graduate/doctoral degrees. A total of $6.5 \%$ were doctors, $60 \%$ were nurses, $12 \%$ were midwives, $8 \%$ were patient counselors, $8.5 \%$ were technicians, and $5 \%$ were healthcare managers. 
Table 4. Socio-demographic characteristics of healthcare workers

\begin{tabular}{|c|c|c|c|}
\hline & & $\mathbf{N}$ & $\%$ \\
\hline \multirow{2}{*}{ Gender } & Female & 166 & 83 \\
\hline & Male & 34 & 17 \\
\hline \multirow{2}{*}{ Marital Status } & Married & 98 & 49 \\
\hline & Single & 102 & 51 \\
\hline \multirow{4}{*}{ Educational Status } & High-School & 22 & 11 \\
\hline & Associate Degree & 19 & 9.5 \\
\hline & Undergraduate Degree & 111 & 55.5 \\
\hline & Post-Graduate/Doctorate & 48 & 24 \\
\hline \multirow{6}{*}{ Working Status } & Doctor & 13 & 6.5 \\
\hline & Nurse & 120 & 60 \\
\hline & Midwife & 24 & 12 \\
\hline & Patient Consultant & 16 & 8 \\
\hline & Technician & 17 & 8.5 \\
\hline & Healthcare Administrator & 10 & 5 \\
\hline Recommending the & Yes & 85 & 42.5 \\
\hline Profession & No & 115 & 57.5 \\
\hline \multirow{2}{*}{ Choosing the Profession } & Willingly & 143 & 71.5 \\
\hline & Unwillingly & 57 & 28.5 \\
\hline Mean Age & $32.17 \pm 8.69$ & $\begin{array}{l}\text { Mean Total Professional } \\
\text { Year }\end{array}$ & $10.56 \pm 9.56$ \\
\hline $\begin{array}{l}\text { Mean Weekly Working } \\
\text { Hours }\end{array}$ & $46.94 \pm 25.69$ & $\begin{array}{l}\text { Mean Total Professional } \\
\text { Year at Current } \\
\text { Workplace }\end{array}$ & $5.66 \pm 6.61$ \\
\hline
\end{tabular}

A total of $42.5 \%$ of the healthcare workers recommended their professions, and $57.5 \%$ did not recommend it. A total of $71.5 \%$ of the healthcare workers chose their profession willingly, and $28.5 \%$ were reluctant to choose their professions. The mean age of healthcare workers was $32.17 \pm 8.69$. The mean weekly working hour was $46.94 \pm 25.69$. The mean total professional year was $10.56 \pm 9.56$, and the mean working duration in their institution was $5.66 \pm 6.61$.

The mean score for determining professional vitality and learned helplessness levels of the healthcare workers are presented in Table 5. The mean professional vitality score was $3.82 \pm 0.48$. In the sub-dimensions, the score in passion was $4.12 \pm 0.59$; vigor $3.64 \pm 0.62$; mastery $4.07 \pm 0.45$, and job satisfaction $3.45 \pm 0.81$.

Table 5. Mean scores of the scales used in the study

\begin{tabular}{lccc}
\hline & Min-Max & Mean & SD \\
\hline Passion & $1-5$ & 4.12 & .59 \\
Vigor & $1-5$ & 3.64 & .62 \\
Mastery & $1-5$ & 4.07 & .45 \\
Job satisfaction & $1-5$ & 3.45 & .81 \\
Professional Vitality & $1-5$ & 3.82 & .48 \\
Learned helplessness & $1-5$ & 2.19 & .47 \\
\hline
\end{tabular}

The mean Learned helplessness score was $2.19 \pm 0.47$. The interpretation of the mean scale scores was made as $" 1.01<\mathrm{X}<1.80$ very low, $1.81<\mathrm{X}<2.60$ low, $2.61<\mathrm{X}<3.40$ moderate, $3.41<$ $\mathrm{X}<4.20$ high, $4.21<\mathrm{X}<5.00$ very high" $[40]$.

The results of the Pearson Correlation Analysis between professional vitality and learned helplessness were presented in Table 6 . 
Table 6. Pearson correlation analysis between professional vitality and learned helplessness

\begin{tabular}{|c|c|c|c|c|c|c|}
\hline & 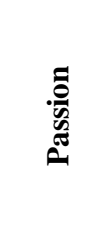 & $\stackrel{\ddot{0}}{\dot{m}}$ & 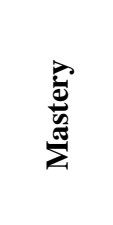 & 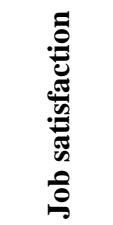 & 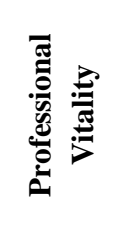 & 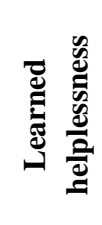 \\
\hline \multirow{2}{*}{ Passion } & 1 & $.599^{* *}$ & $.326^{* *}$ & $.593^{* *}$ & $.818^{* * *}$ & $-.379^{* * *}$ \\
\hline & & .000 & .000 & .000 & .000 & .000 \\
\hline \multirow{2}{*}{ Vigor } & $.599^{* *}$ & 1 & $.282^{* *}$ & $.617^{* * *}$ & $.823^{* *}$ & $-.361^{* *}$ \\
\hline & .000 & & .000 & .000 & .000 & .000 \\
\hline \multirow{2}{*}{ Mastery } & $.326^{* *}$ & $.282^{* *}$ & 1 & $.315^{* *}$ & $.553^{* *}$ & $-.478^{* * *}$ \\
\hline & .000 & .000 & & .000 & .000 & .000 \\
\hline \multirow{2}{*}{ Job satisfaction } & $.593^{* *}$ & $.617^{* *}$ & $.315^{* *}$ & 1 & $.867^{* *}$ & $-.490^{* * *}$ \\
\hline & .000 & .000 & .000 & & .000 & .000 \\
\hline \multirow{2}{*}{ Professional vitality } & $.818^{* *}$ & $.823^{* *}$ & $.553^{* *}$ & $.867^{* * *}$ & 1 & $-.545^{* *}$ \\
\hline & .000 & .000 & .000 & .000 & & .000 \\
\hline \multirow{2}{*}{ Learned helplessness } & $-.379^{* * *}$ & $-.361^{* *}$ & $-.478^{* *}$ & $-.490^{* * *}$ & $-.545^{* *}$ & 1 \\
\hline & .000 & .000 & .000 & .000 & .000 & \\
\hline
\end{tabular}

When Table 6 was examined, it was found that there was a significant and negative relation between professional vitality and learned helplessness ( $\mathrm{r}:-.545 ; \mathrm{p}<0.000)$. It was determined that there was a significant and negative relation between all professional vitality subcomponents (i.e. passion, vigor, mastery, and job satisfaction), and learned helplessness ( $\mathrm{p}<0.001)$. In professional vitality subcomponents, job satisfaction and learned helplessness had the highest correlation coefficient (r:$.490 ; \mathrm{p}<0.001)$; the vigor sub-dimension had the lowest correlation coefficient among learned helplessness.

Regression Analysis Methods were preferred to determine the effect of professional vitality on learned helplessness (Table 7). The Linear Regression Analysis Model was specified as $\mathrm{Y}=\mathrm{a}+\mathrm{bX}(41)$.

The regression analysis model established (F:83.832; $<<0.001)$, and the test value (t:-9.156; $\mathrm{p}<0.001)$ were statistically significant. It was observed that there was a significant and negative relation between professional vitality and learned helplessness (R:-.545; $\mathrm{p}<0.001$ ). The specificity coefficient value of the established model was $\mathrm{R}^{2}$ : .297. In this respect, it shows that the effect of professional vitality of healthcare workers accounted for $29.7 \%$ of the effect on learned helplessness perceptions. A one-unit increase in professional vitality reduced the learned helplessness levels of healthcare workers by -.530 . When regression analysis coefficient values were examined in the relevant table, it was seen that professional vitality perceptions of healthcare workers had a significant and negative effect on learned helplessness levels; and $\mathrm{H}_{1}$ Hypothesis was accepted. According to the regression analysis, if the estimated model is $\mathrm{Y}=\mathrm{a}+\mathrm{bX}$ [41], and if, a:4.218 and b:-0.530. $\mathrm{Y}=4.218$ 0.530X ( $\mathrm{X}=$ Professional Vitality). 
Table 7. Effect of professional vitality on learned helplessness

\begin{tabular}{|c|c|c|c|c|c|c|c|}
\hline \multirow[t]{2}{*}{ Variable } & \multicolumn{2}{|c|}{$\begin{array}{c}\text { Non-standardized } \\
\text { coefficients }\end{array}$} & \multirow{2}{*}{$\begin{array}{c}\text { Standardized } \\
\text { coefficients }\end{array}$} & \multirow[t]{2}{*}{$\mathrm{t}$} & \multirow[t]{2}{*}{$\mathrm{p}$} & \multirow[t]{2}{*}{$\mathrm{F}$} & \multirow{2}{*}{$\begin{array}{l}\text { Model } \\
\text { (p) }\end{array}$} \\
\hline & B & Std. Error & & & & & \\
\hline Constant & 4.218 & .223 & & 18.908 & $.000 * *$ & 83.832 & $.000 *$ \\
\hline $\begin{array}{c}\text { Professional } \\
\text { Vitality }\end{array}$ & -.530 & .058 & -.545 & -9.156 & $.000 * *$ & & \\
\hline $\mathrm{R}^{2}: .297 \mathrm{R}:-.545$ & $* \mathrm{p}<0.05$ & $* * \mathrm{p}<0.01$ & $\mathrm{~d} \mathrm{R}^{2}: .294$ & & & & \\
\hline
\end{tabular}

Multiple Regression Analysis was made to determine the effect of the professional vitality (i.e. passion, vigor, mastery, and job satisfaction) sub-dimensions on learned helplessness (Table 8). Firstly, the Durbin-Watson Coefficient (i.e. the auto-correlation) value was examined among the analysis criteria. If this value is between 1.5 and 2.5, it shows that there is no problem in terms of autocorrelation in Multiple Linear Regression Analysis [41].

Table 8. Effect of professional vitality scale sub-dimensions on learned helplessness

\begin{tabular}{|c|c|c|c|c|c|c|}
\hline \multirow[t]{2}{*}{ Variable } & \multicolumn{2}{|c|}{ Non-standardized coefficients } & \multirow{2}{*}{$\begin{array}{l}\text { Standardized } \\
\text { coefficients }\end{array}$} & \multirow[t]{2}{*}{$\mathrm{t}$} & \multirow[t]{2}{*}{$\mathrm{p}$} & \multirow[t]{2}{*}{ VIF } \\
\hline & B & Standard Error & & & & \\
\hline Constant & 4.592 & .277 & & 16.554 & $.000^{* *}$ & \\
\hline Passion & -.042 & .062 & -.052 & -.674 & .501 & 1.824 \\
\hline Vigor & -.019 & .060 & -.025 & -.316 & .753 & 1.873 \\
\hline Mastery & -.365 & .064 & -.349 & -5.677 & $.000^{* *}$ & 1.152 \\
\hline Job satisfaction & -.195 & .046 & -.334 & -4.254 & $.000 * *$ & 1.877 \\
\hline F: $27.364 \quad R^{2}: .360$ & R: .600 $\quad * p<0$ & $* * \mathrm{p}<0.01$ & cted $\mathrm{R}^{2}: .346$ & son: 1.71 & & \\
\hline
\end{tabular}

As the second criterion, it is expected that the Variance Inflation Factor-VIF coefficients are less than 10, which will show that there are no multiple correlation problems [41]. The Durbin-Watson coefficient was 1.713, and VIF ranged between 1.824 and 1.877. In this respect, it may be speculated that there are no autocorrelation and multiple connection problems in multiple linear regression analysis.

Multilinear Regression Analysis Model [41] is defined as $\left(\mathrm{Y}=\mathrm{a}+\mathrm{bX}+\mathrm{cX} \mathrm{X}_{2}+\mathrm{dX} \mathrm{X}_{3}+\ldots\right)$. The established model (F:27.364; $\mathrm{p}<0.01$ ) was statistically significant. The $\boldsymbol{t}$ statistical values, which show the significance of regression coefficients, were insignificant for passion $(-0.674 ; p>0.05)$ and vigor (t:-0.316; $\mathrm{p}>0.05)$ dimensions; however, they were highly significant for mastery $(\mathrm{t}:-5.677 ; \mathrm{p}<0.01)$ and job satisfaction (t:-4.254; $\mathrm{p}<0.01)$. The specificity value of the established model was $\mathrm{R}^{2}$ : .346. In agreement with this outcome, the effect of mastery and job satisfaction subdimensions from professional vitality subdimensions was statistically significant and negative. According to the predicted regression analysis model, although other subscales were constant, a one-unit increase in mastery dimension decreased learned helplessness by -.365 , and a one-unit increase in the job satisfaction sub-dimension caused a decrease by -.195 on helplessness. The effect of mastery and job satisfaction sub-dimension from scale sub-dimension was significant and negative. In line with these results, the $\mathrm{H}_{1 \mathrm{c}} \mathrm{veH}_{1 \mathrm{~d}}$ hypotheses were accepted, and $\mathrm{H}_{1 \mathrm{a}}$ and $\mathrm{H}_{1 \mathrm{~b}}$ were rejected (Table 9). According to the data given in Table 7, If the Multilinear Regression Analysis Model [41] is $\left(\mathrm{Y}=\mathrm{a}+\mathrm{bX}{ }_{1}+\mathrm{cX} \mathrm{X}_{2}+\mathrm{dX}_{3}+\ldots\right)$, and if $\mathrm{a}=4.592 ; \mathrm{b}=-.042 ; \mathrm{c}=-.019 \mathrm{~d}=-.365$ and $\mathrm{e}=-.195, \mathrm{Y}=4.592-0.042 \mathrm{X}_{1-}$ 
$0.019 \mathrm{X}_{2}-0.365 \mathrm{X}_{3}-0.195 \mathrm{X}_{4}\left(\mathrm{X}_{1}=\right.$ Passion; $\mathrm{X}_{2}=$ Vigor; $\mathrm{X}_{3}=$ Mastery; $\mathrm{X}_{4}=$ Job satisfaction $)$. When Table 9 is examined, the developed hypotheses were mostly accepted.

Table 9. Acceptance or refusal status of the hypotheses developed in the scope of the study

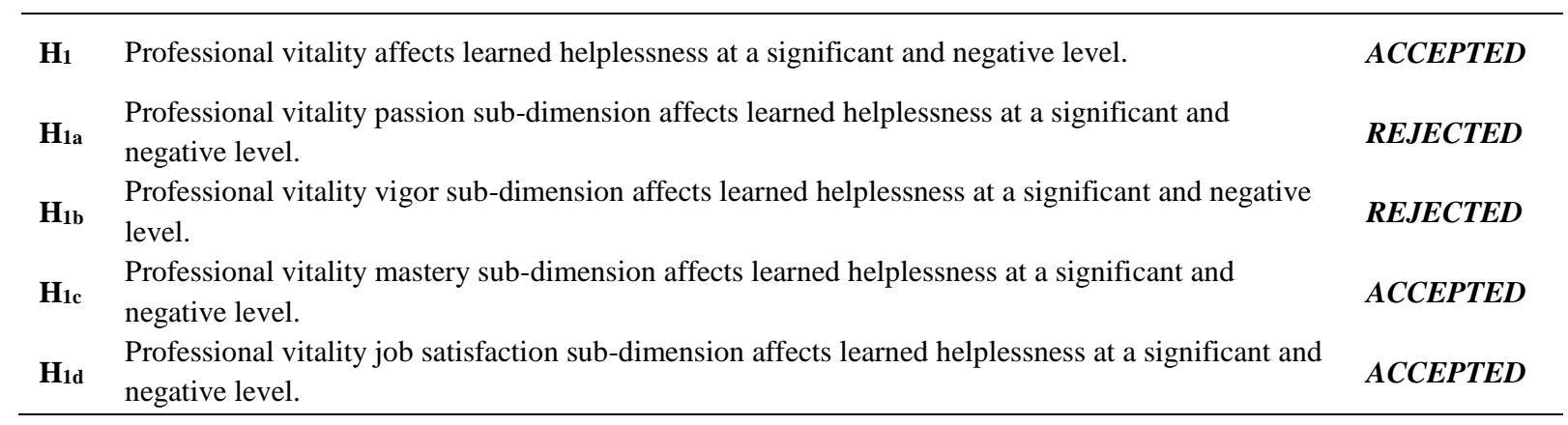

\section{Discussion}

In this study, the effects of the professional vitality of healthcare workers during the Covid-19 pandemia process on learned helplessness were evaluated. With this evaluation, the main purpose was to determine the evidence that would contribute to the strengthening of "the heroes of the pandemia: healthcare workers".

Professional vitality of the healthcare workers was at high levels and was compatible with the results of the studies done in the literature [21, 35]. The fact that the level was high despite the negativity of the pandemia is a pleasing result. No studies were detected on the pandemia period concerning the subject. For this reason, concepts that did not belong to the pandemia period but could be associated were included.

The relation between professional vitality and security, organizational commitment [42], work performance [26], innovation [43], creativity [44], burnout [45], and agility [46] was examined by previous researchers. When professional vitality perception increases in a positive way, this provides an increase in these important factors [42, 26, 44]. Employees also tend to work in a more secure way [42]. In their study, Brauch et al. reported that as professional vitality increased, the perception of life satisfaction would also increase in the same way [21]. Tummers et al. also found in their study that professional vitality increased work autonomy [47]. In Hennekam's study conducted with older employees, it was found that there were significant and positive relations between vitality and job performance [23]. In this context, it was reported that with increased vitality perception in employees, older employees who had higher vitality levels prevented early retirement, performed well, reached higher positions in their organizations as a result of high work performance, and received higher salaries than older employees [23]. The success of an employee at work, social interactions in the workplace, and a multicultural work environment may provide positive ideas about subjective goodness [48]. Previous studies also show that higher vitality increases the resilience of people to physical and viral stressors, and make them less vulnerable to diseases [49, 47].

Learned helplessness level is low in healthcare workers, which is in line with the literature [50. 51]. This result will improve the quality of the healthcare delivery and avoid that the vitality of the employees decreases during the pandemia. Despite all the negations, the low level of helplessness might be because Turkey has been one of the most reliable and successful countries during the 
pandemia. The low number of mortality is the most concrete indication of this outcome. Many supportive factors like the high development level of second-line treatment institutions, the equipment of healthcare workers, early intervention, spiritual values, level of compliance with the rules of the people may also have increased the success rates and kept helplessness levels low. No data are available regarding learned helplessness in the pandemia process. However, it can be speculated that reducing the helplessness levels can be a motivator to overcome problems in the pandemia process and that they will have positive contributions in many ways like in increasing the performance and providing efficiency both in individual and institutional terms.

The relations between depression, self-confidence, scientific thinking skills [52], optimism, and pessimism were examined in previous studies [53]. In the study conducted by Yüksel and Özkiraz, helplessness was reported to be the most important problem in the public sector and the most important cause of the poor performance of employees [32]. In the study of Barutçu and Çöllü, it was reported that there was a significant and negative relation between learned helplessness and belief in overcoming difficulties and motivation [31]. In the study of Polatçı and Boyraz conducted with teachers, it was found that the role uncertainty was an important predictor for learned helplessness, and learned helplessness was an important predictor for job satisfaction [54]. Chen and Mykletun reported that organizational injustice caused learned helplessness, and learned helplessness caused anti-production behavior [55]. It is possible to speculate that similar results are true for the healthcare sector.

\section{Result and Recommendations}

It was determined in the present study that the professional vitality of healthcare workers had a negative impact on learned helplessness perceptions of the healthcare workers during the pandemia process.

The impacts on different sectors were examined in previous studies conducted on the subject. For this reason, it is recommended that more studies are conducted in the healthcare sector, which is very important for life. Studies must be conducted in different healthcare institutions, and the results must be compared.

It may also be recommended that open communication is established, shift hours are limited, resting areas are organized, basic and supportive training are provided regarding the patient management in Covid-19, and the use of preventive equipment to increase the vitality of healthcare workers and reduce their helplessness.

Ethical Permission: Before the commencement of the study, the ethical board permission was obtained from the Scientific Research and Publishing Ethics Board of Osmaniye Korkut Ata University (dated 19.03.2020. and with the registry number E.1896). The participants took part in the study on a voluntary basis. Institutions were informed.

The compliance to the Research and Publication Ethics: This study was carried out in accordance with the rules of research and publication ethics 


\section{References}

[1] Bao, Y., Sun, Y., Meng, S., Shi, J., Lu, L., "2019-nCoV epidemic: address mental health care to empower society", The Lancet, 395(10224), e37-e38, 2020. Doi: https://doi.org/10.1016/ S0140-6736(20)30309-3.

[2] Huang, C., Wang, Y., Li, X., Ren, L., Zhao, J., Hu, Y., \& Cao, B, "Clinical features of patients infected with 2019 novel coronavirus in Wuhan, China", The Lancet, 395(10223), 497-506, 2020. Doi: https://doi.org/10.1016/S0140-6736(20)30183-5.

[3] Mo, Y., Deng, L., Zhang, L., Lang, Q., Liao, C., Wang, N., \& Huang, H., "Work stress among Chinese nurses to support Wuhan in fighting against COVID- 19 epidemic", Journal of Nursing Management, 28(5), 1002-1009, 2020. Doi: https://doi.org/10.1111/jonm.13014.

[4] Wang, J., Cheng, Y., Zhou, Z., Jiang, A., Guo, J., Chen, Z., \& Wan, Q., “Psychological status of Wuhan medical staff in fighting against COVID-19", Medical Journal of Wuhan University, 4 (41), 547-550, 2020.

[5] Huang, H., Liu, L., Yang, S., Cui, X., Zhang, J., \& Wu, H., "Effects of job conditions, occupational stress, and emotional intelligence on chronic fatigue among Chinese nurses: a cross-sectional study", Psychology Research and Behavior Management, 12, 351-360, 2019. Doi: 10.2147/ PRBM.S207283.

[6] Triana-Palencia, E., Cárdenas-Cárdenas, L.M., Juárez-García, A., Quiroz-Muysina, J., Idrovo, A.J.,"Use of assessment scales, turnover and job strain in nursing staff: A study in a Colombian hospital", Journal of Nursing Management, 27(1), 42-51, 2018. Doi:

https://doi.org/10.1111/jonm.12647.

[7] Wu, J., Wu, X., Wu, F., Dia, Y., Dechun, C., Gong, X., "Survey of sleep quality of clinical front-line nurses and its influencing factors in the fight against new coronavirus pneumonia", Nursing Research, 34(4), 558-562, 2020.

[8] Huang, L., Lei, W., Xu, F., Liu, H., \& Yu, L., "Emotional responses and coping strategies in nurses and nursing students during Covid-19 outbreak: A comparative study" PLoS One, 15(8), e0237303, 2020, https://doi.org/10.1371/journal.pone.0237303.

[9] Malinauskiene, V., Leisyte, P., Romualdas, M., Kirtiklyte, K., "Associations between self-rated health and psychosocial conditions, lifestyle factors and health resources among hospital nurses in Lithuania", Journal of Advanced Nursing, 67(11), 2383-2393, 2011. Doi: https://doi.org/10.1111/j.1365-2648.2011.05685.x.

[10] Teles, M. A. B., Barbosa, M. R., Vargas, A. M. D., Gomes, V. E., e Ferreira, E. F., de Barros Lima, A. M. E., \& Ferreira, R. C., "Psychosocial work conditions and quality of life among primary health care employees: A cross sectional study", Health Quality of Life Outcomes, 12, 1-12, 2014. Doi: https://doi.org/10.1186/1477-7525-12-72. (2014).

[11] Liu, Y., Aungsuroch, Y., "Work stress, perceived social support, self-efficacy and burnout among Chinese registered nurses", Journal of Nursing Management, 27(7), 1445-1453, 2019. Doi: https://doi.org/10.1111/jonm.12828 
[12] Zhang, C., Yang, L., Liu, S., Ma, S., Wang, Y., Cai, Z., ... \& Zhang, B.., "Survey of insomnia and related social psychological factors among medical staff involved in the 2019 novel coronavirus disease outbreak", Frontiers in Psychiatry, 11, 1-9, 2020. Doi: https://doi.org/10.3389/fpsyt.2020.00306

[13] Fernandez, R., Lord, H., Halcomb, E., Moxham, L., Middleton, R., Alananzeh, I., \& Ellwood, L., "Implications for COVID-19: A systematic review of nurses' experiences of working in acute care hospital settings during a respiratory pandemic", International Journal of Nursing Studies, 111, 1-26, 2020. Doi: https://doi.org/10.1016/j.ijnurstu.2020.103637.

[14] Cheung, T., Fong, T.K.H., Bressington, D., "COVID- 19 under the SARS Cloud: Mental health nursing during the pandemic in Hong Kong", J Psychiatr Ment Health Nurs, 28, 115-117, 2021. Doi: https://doi.org/10.1111/jpm.12639.

[15] Yin, X., Zeng, L., "A study on the psychological needs of nurses caring for patients with coronavirus disease 2019 from the perspective of the existence, relatedness, and growth theory", International Journal of Nursing Sciences, 7(2), 157-160, 2020. Doi: https://doi.org/10.1016/j.ijnss.2020.04.002

[16] Sun, N., Wei, L., Shi, S., Jiao, D., Song, R., Ma, L., ... \& Wang, H., "A qualitative study on the psychological experience of caregivers of COVID-19 patients", American Journal of Infection Control, 48 (6), 592-598, 2020. Doi: https://doi.org/10.1016/j.ajic.2020.03.018.

[17] Pappa, S., Ntella, V., Giannakas, T., Giannakoulis, V.G., Papoutsi, E., Katsaounou. P., "Prevalence of depression, anxiety, and insomnia among healthcare workers during the COVID19 pandemic: Asystematic review and meta-analysis", Brain, Behavior, and Immunity, 88, 901 907, 2020. Doi: https://doi.org/10.1016/j.bbi.2020.05.026.

[18] Lai, J., Ma, S., Wang, Y., Cai, Z., Hu, J., Wei, N., et al., "Factors associated with mental health outcomes among health care workers exposed to coronavirus disease 2019", JAMA Network Open, 3(3), e203976, 2020. Doi: 10.1001 / jamanetworkopen.2020.3976.

[19] Tan, B. Y., Chew, N. W., Lee, G. K., Jing, M., Goh, Y., Yeo, L. L., ... \& Sharma, V. K., "Psychological impact of the COVID-19 pandemic on health care workers in Singapore", Annals of Internal Medicine, 173(4), 317-320, 2020. Doi: https://doi.org/10.7326/M20-1083

[20] Bohlken, J., Schömig, F., Lemke, M.R., Pumberger. M., Riedel-Heller, S.G., "COVID19Pandemic: Stress experience of healthcare workers - a short current review", Psychiatrische Praxis, 47 (4), 190-197, 2020. Doi: https://doi.org/10.1055/a-1159-5551.

[21] Baruch, Y., Grimland, S., Vigoda-Gadot, E., "Professional vitality and career success: Mediation, age and outcomes", European Management Journal, 32(3), 518-527, 2014. Doi: https://doi.org/10.1016/j.emj.2013.06.004

[22] Chu, F., Long, Y., Guo, M., "Determinants and outcomes of professional vitality: Evidence from China", Social Behavior and Personality: An International Journal, 43(8), 1335-1345, 2015. Doi: https://doi.org/10.2224/sbp.2015.43.8.1335 
[23] Hennekam, S., "Vitality of older workers and its relationship with performance, career satisfaction and career success", Management Avenir, 1, 15-32, 2016. Doi: https://doi.org/10.3917/mav.083.0015

[24] Porath, C., Spreitzer, G., Gibson, C., \& Garnett, F. G., "Thriving at work: Towards its measurement, construct validation and theoretical refinement", Journal of Organizational Behavior, 33(2), 250-275, 2012. Doi: https://doi.org/10.1002/job.756

[25] Khany, R., Malekzadeh, P., "Associations among EFL teachers' professional identity, professional vitality, and creativity", Teaching English Language, 9(2), 37-74, 2015. Doi: https://dx.doi.org/10.22132/tel.2015.53724.

[26] Carmeli, A., Positive work relationships, vitality, and job performance. In Emotions in groups, organizations and cultures, Emerald Group Publishing Limited, 2009.

[27] Nix, G.A., Ryan, R.M., Manly, J.B., Deci, E.L., "Animation through self-regulation: The effects of autonomous and controlled motivation on happiness and vitality", Experimental Journal of Social Psychology, 35, 266-284, 1999. Doi: https://doi.org/10.1006/jesp.1999.1382.

[28] Ryan, R.M., Frederick, C., "On energy, personality, and health: Subjective vitality as a dynamic reflection of wellbeing", Journal of Personality, 65 (3), 529-565, 1997. Doi https://doi.org/10.1111/j.1467-6494.1997.tb00326.x.

[29] Usher, K., Bhullar, N., Jackson, D., "Life in the pandemic: Social isolation and mental health", Journal of Clinical Nursing, 29 (15-16), 2756-2757, 2020. Doi: https://doi.org/10.1111/jocn.15290

[30] Shaw, S., "Hopelessness, helplessness and resilience: The importance of safeguarding our trainees' mental wellbeing during the COVID-19 pandemic", Nurse Education In Practice, 44, 102780, 2020. Doi: https://dx.doi.org/10.1016\%2Fj.nepr.2020.102780

[31] Barutçu, E., Çöllü, B., “Öğrenilmiş çaresizlik ile motivasyon arasındaki ilişki: Pamukkale üniversitesi öğrencileri üzerinde bir araştırma", Süleyman Demirel Üniversitesi İktisadi ve İdari Bilimler Fakültesi Dergisi,25(1), 1-13, 2020.

[32] Yüksel, F., Özkiraz, A., "The main problem of Turkish public administration: Learned helplessness", African Journal of Business Management, 6(4), 1214-1221, 2012.

[33] Ateş, H., "Impacts of learned helplessness theory on new public management reforms: A case study in Turkish health sector", Medeniyet Araştırmaları Dergisi, 3(5), 43-61, 2018.

[34] Harvey, T.A., "Professional Vitality and The Principalship: A Construct Validity Study", Unpublished Ph. D. thesis, University of Maine, 2002.

[35] Uzunbacak, H.H., Akçakanat, T.,"Mesleki canlılık ölçeği Türkçe formunun geçerlik ve güvenirlik çalışması", Journal of Social And Humanities Sciences Research, 5 (28), 3222-3230, 2018.

[36] Quđnless, F.W., Nelson, M.A., "Development of a measure of learned helplessness", Nursing Research., 37 (1), 11-15, 1988. Doi: https://psycnet.apa.org/doi/10.1097/00006199-19880100000003. 
[37] Boysan, M., Çok Örneklemli Yapısal Eşitlik Modelleri, Yüksek Lisans Tezi, Yüzüncü Yıl Üniversitesi, Van, Türkiye, 2006.

[38] Yavaş, T., Ortaöğretim Okul Yöneticileri ve Öğretmenlerinin Öğrenilmiş Çaresizlik, Tükenmişlik ve Öz-Yeterlik Algılarının Örgütsel Öğrenme Düzeylerine Etkileri, Doktora Tezi, Firat Üniversitesi, Elazığ, Türkiye, 2012.

[39] Hair, J.F., Black, W.C., Babin, B.J., Anderson. R.E., Tatham, R.L., Multivariate Data Analysis, Essex, England, 2013.

[40] Öztürk, Z., Yılmazer, Ö., Erdem, Ö.,"Hastanelerde sağlık çalışanlarının motivasyon düzeylerinin örgütsel bağl1lıklarına etkileri: Kırıkkale ili örneği”,Uluslararası Sağllk Yönetimi ve Stratejileri Araştırma Dergisi, 5(1), 21-50, 2019.

[41] Alpar, R., Spor, Sağlık ve Eğitim Bilimlerinde Örneklerle Uygulamalı Istatistik ve GeçerlilikGüvenirlik, Detay Yayıncılık, Ankara, 2018.

[42] Dejoy, D.M., Della, L.J., Vandenberg, R.J., Wilson, M.G., "Making work safer: Testing a model of social exchange and safety management", Journal of Safety Research, 41(2), 163-171, 2010. https://doi.org/10.1016/j.jsr.2010.02.001.

[43] Carmeli, A., Spreitzer, G.M., "Trust, connectivity, and thriving: Implications for innovative behaviors at work", Journal of Creative Behavior, 43(3), 169-191, 2009. Doi: https://doi.org/10.1002/j.2162-6057.2009.tb01313.x.

[44] Kark, R., Carmeli, A., "Alive and creating: The mediating role of vitality and aliveness in the relationship between psychological safety and creative work involvement", Journal of Organizational Behavior, 30(6), 785-804, 2009. Doi: https://doi.org/10.1002/job.571.

[45] Vallerand. R.J., Paquet, V., Philippe, F.L., Charest, J., "On the role of passion in work in burnout: A process model", Journal of Personality, 78(1), 289-312, 2010. Doi: https://doi.org/10.1111/j.1467-6494.2009.00616.x.

[46] Dries, N., Vantilborgh, T., Pepermans, R., "The role of learning agility and career variety in the identification and development of high potential employees", Personnel Review, 41(3), 340358, 2012. Doi: https://doi.org/10.1108/00483481211212977.

[47] Tummers, L., Steijn, B., Nevicka, B., Heerema, M., "The effects of leadership and job autonomy on vitality: Survey and experimental evidence", Review of Public Personnel Administration, 38(3), 355-377, 2018. Doi: https://doi.org/10.1177/0734371X16671980.

[48] Basinska, B.A., Thriving in a multicultural workplace in. In Intercultural interactions in the multicultural workplace (pp. 109-121). Springer, Cham, 2017.

[49] Ryan, R.M., Deci, E.L., "From ego depletion to vitality: Theories and findings related to facilitating the available energy for the self", Social and Personality Psychology Compass, 2 (2), 702 - 717, 2008. Doi: https://doi.org/10.1111/j.1751-9004.2008.00098.x.

[50] Solomon, K., "Social antecedents of learned helplessness in the health care setting", The Gerontologist, 22(3), 282-287, 1982. Doi: https://doi.org/10.1093/geront/22.3.282. 
[51] Yaman, A., Esen, İ., Derkuş, S., "A study on the liaison between learned helplessness and academic language achievement", Çukurova Üniversitesi Sosyal Bilimler Enstitüsü Dergisi, 20(2), 457-469, 2011.

[52] Büyükşahin, Ç.G., Gündoğdu H. "Stres, umutsuzluk, ve annelerin öğrenilmiş̧ çaresizliğinin ergenlerin öğrenilmiş çaresizliğini yordama düzeyleri”, Türk Psikolojik Danışma ve Rehberlik Dergisi, 5(43), 21-34, 2015.

[53] Seligman, M. E., Köroğlu, E., \& Akbaş, S. K., “Öğrenilmiş iyimserlik”. HYB basım yayın. Ankara, 2007.

[54] Polatçı, S., Boyraz, E., “Öğretmenlerin öğrenilmiş güçlülüklerinin kaynak ve sonuçlarına ilişkin bir model önerisi”, Atatürk Üniversitesi İktisadi ve İdari Bilimler Dergisi, 24(4), 137-154, 2010.

[55] Chen, S.P., Mykletun, R.J., "Beyond post-downsizing organisational injustice and counterproductive work behaviours: Antecedents and consequences of learnt helplessness", International Journal of Business and Management, 10 (6), 1-14, 2015. Doi: doi:10.5539/ijbm.v10n6p1. 